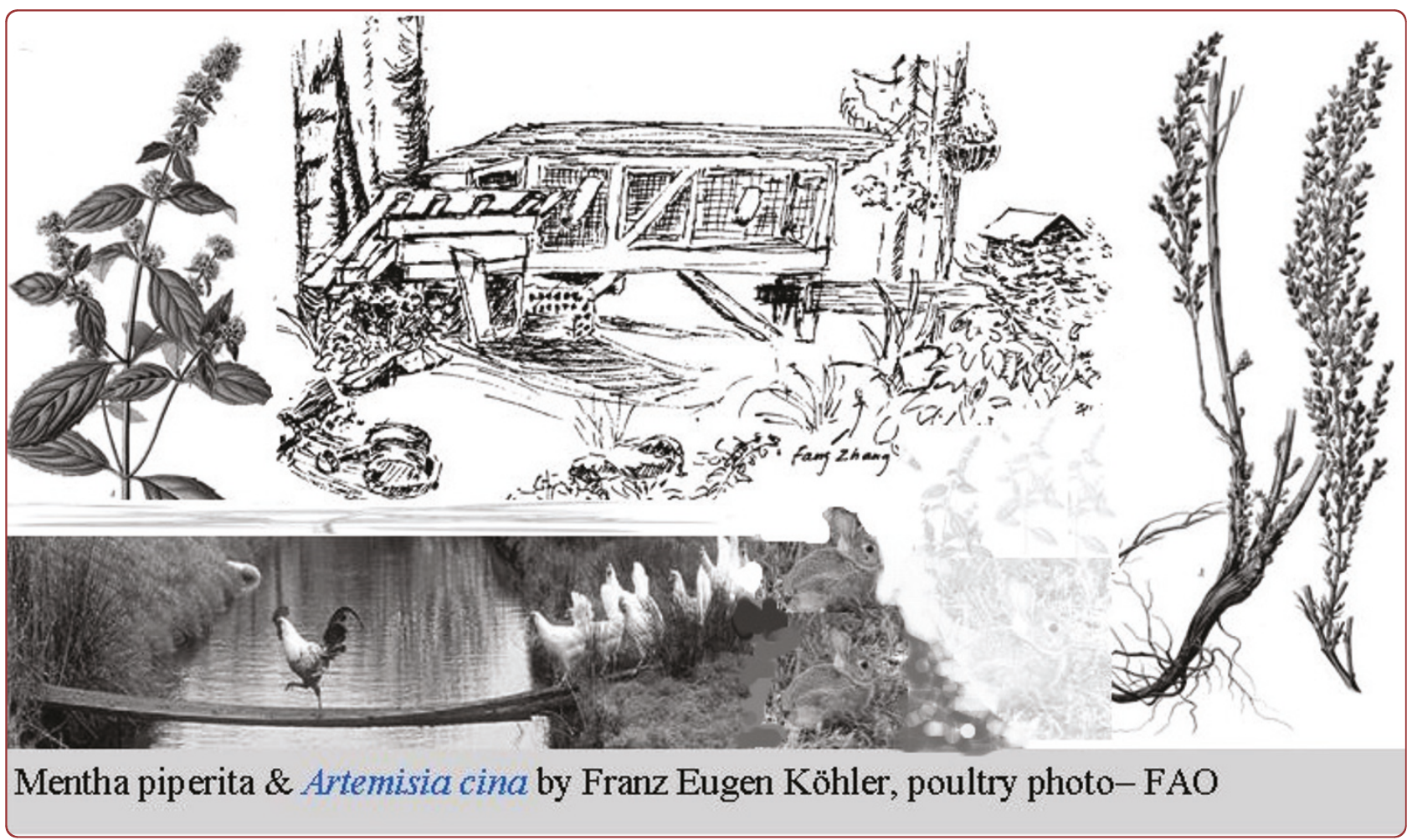

\title{
Organic parasite control for poultry and rabbits in British Columbia, Canada
}

Lans and Turner

C Biomed Central 


\title{
Organic parasite control for poultry and rabbits in British Columbia, Canada
}

\author{
Cheryl Lans ${ }^{1 *}$ and Nancy Turner ${ }^{2}$
}

\begin{abstract}
Plants used for treating endo- and ectoparasites of rabbits and poultry in British Columbia included Arctium lappa (burdock), Artemisia sp. (wormwood), Chenopodium album (lambsquarters) and C. ambrosioides (epazote), Cirsium arvense (Canada thistle), Juniperus spp. (juniper), Mentha piperita (peppermint), Nicotiana sp. (tobacco), Papaver somniferum (opium poppy), Rubus spp. (blackberry and raspberry relatives), Symphytum officinale (comfrey), Taraxacum officinale (common dandelion), Thuja plicata (western redcedar) and Urtica dioica (stinging nettle).
\end{abstract}

Keywords: poultry, rabbits, ethnoveterinary medicine, ectoparasites, endoparasites, British Columbia

\section{Introduction}

Consumers, butchers and restaurant-owners are increasingly demanding that meat animals be reared in environmentally-sensitive ways that also take animal welfare concerns into consideration (e.g. access to pasture); these organic farming management practices also improve meat quality [1-5]. The meat from poultry and rabbits is more efficient to produce in terms of land use, feed and water use than beef and pork and thus produces a lower environmental impact [6-10]. Some consumers are also concerned about chemical residues (like flubendazole) in meat $[11,12]$. The access to pasture demanded by animal welfare agents increases the need for parasite control in food animals $[11,13]$. Organic agriculture allows a restricted number of substances to be used for pest control.

Some conventional livestock farmers add subclinical levels of antibiotics to the animal feed of millions of food animals as growth promoters [14]. Some of these antibiotics are not absorbed and are excreted in manure which is then applied as a fertilizer to food crops. As much as $387 \mathrm{~g}$ of chlortetracycline and $202 \mathrm{~g}$ of tylosin per hectare is estimated to be added to the soil with the application of pig manure. Greenhouse studies conducted on corn (Zea mays L.), green onion (Allium cepa L.), and cabbage (Brassica oleracea L. Capitata group) showed that all three crops absorbed chlortetracycline from pig manure

\footnotetext{
* Correspondence: cher2lans@netscape.net

'PO Box 72045 Sasamat, Vancouver, British Columbia, V6R4P2, Canada

Full list of author information is available at the end of the article
}

but tylosin was not absorbed [14]. Botanical and mineral products used for animal health are less likely to become soil contaminants than chlortetracycline since they are natural products.

Extracts and essential oils of various plants such as Rosmarinus officinalis L. (rosemary), Mentha piperita L. and M. virdis (L.) L.(mints), Artemisia absinthium L. (absinthium, or wormwood), Chenopodium ambrosioides L. (epazote), Thymus vulgaris L. (thyme) and Origanum vulgare L. (oregano) have potential for use as parasite controls because they have insecticidal activity. For example, essential oils of Melissa officinalis L. (0.12\%) and Mentha piperata L. (1.3\%) caused mortality and induced repellency in adult females of the carmine spider mite (Tetranychus cinnabarinus Boisd.; Acarina: Tetranychidae) and egg-laying was reduced [15]. Nymphs of cayenne tick (Amblyomma cajennense (Fabricius); Acari: Ixodidae) were susceptible to ethanolic extracts of Chenopodium ambrosioides [16].

\subsection{Ethnoveterinary research}

Ethnoveterinary medicinal research is often undertaken as part of a community-based approach that serves to improve animal health and provide basic veterinary services in underserved areas [17]. This paper reports on research that documented and validated (in a nonexperimental way) ethnoveterinary medicines used for parasite control by small-scale, organic livestock rabbit and poultry farmers in British Columbia (B.C.), Canada.

\section{() Biomed Central}




\subsection{Organic rabbit and poultry production}

Most rabbits are raised on farms for home consumption or for the pet industry. In 2001 over 17,000 rabbits on 264 farms were reported; this figure represented a $14 \%$ decline in the number of rabbits and a $71 \%$ decline in the number of farms with rabbits [18]. There were no certified organic rabbit producers in British Columbia and only two in Canada $[19,20]$.

In the case of poultry, organic egg production represented less than 2 percent of all egg production in B.C. and less than half of 1 percent across Canada [21]. Small-scale farmers produce 100,000 chickens annually. Flocks containing less than 99 layers, or 199 broilers, are not covered by the provincial quota and are not regulated by the provincial Egg or Chicken Marketing Boards.

There are three categories of specialty chicken regulated by the Provincial Marketing Boards. These categories contain $3.6 \%$ of the total permit allocation for all chicken production in B.C. $(1,085,005 \mathrm{~kg}$ live weight) [22]. There were 19 farmers in the specially-fed/housed chicken category, holding half of the allocated permits; 16 of the 19 farmers were located in the Lower Mainland area of B.C. This specially-fed/housed category includes vegetable-fed chickens, chickens raised with no or limited antibiotic use, and chickens classified as organic, certified organic, natural, range fed, SPCA certified, Cornish and roasters [22]. There were also 19 small-scale farmers in the farm gate category, and 20 Lower Mainland farmers in a third category who raised Asian specialty chickens (e.g. Silkies, Taiwanese). The annual economic value of the specialty chicken industry was estimated at $\$ 18.0$ million dollars, or $7.7 \%$ of the entire economic value of all chicken production in B.C. (\$232.7 million in 2002); $54.9 \%$ of the value of broiler hatching egg production of $\$ 32.8$ million and $20 \%$ of the economic value of egg production of $\$ 90$ million [22].

\section{Materials and methods}

\subsection{Data collection}

Ethnoveterinary data for British Columbia was collected for a wide range of animals who were under the care of farmers, veterinarians and animal care specialists over a six-month period in 2003. All of the available literature about livestock farmers and the secondary literature on ethnomedicinal plants, folk medicine and related fields in British Columbia was reviewed $[23,24]$. The research area included south Vancouver Island, the Lower Mainland, and the Thompson/Okanagan region of the Interior. A purposive sample of livestock farmers was used to find 60 key informants. Participants were identified from membership lists of organic farmers, horse and dog breeders and trainers, horse stables, sheep, cattle and goat breeders, naturopaths, farm women's networks, meat processors, holistic veterinarians and other specialists in alternative medicine for animals. Ten farmers (nine poultry and one rabbit farmer), and three herbalists provided the data presented here on plants used for poultry and rabbit parasite control. The participating poultry farmers were either organic (commercial operations) or farm-gate producers, including one also raising Asian specialty chickens.

Two visits were made to each farm or respondent, with interviews conducted on the first visit to identify the ethnoveterinary remedies known to and/or used by the individual. The data form was revised on campus and then posted to the relevant address and followed up with a phone interview or a second visit to re-confirm the accuracy of the data (Figure 1). During the second visit, the data recorded and summarized from the initial interview was checked and elaborated on, in order to establish that dosages were accurately noted, for input on content, and to clarify any points. The respondentapproved data forms were compiled into a draft manual.

Where possible, voucher specimens of plants established as remedies were collected by two student ethnobotanists and two herbalists, identified, processed and labelled, then deposited in the University of Victoria herbarium.

The plant-based remedies were evaluated for safety and efficacy with a non-experimental method, prior to including them in the final version of the manual. Published sources such as journal articles, books, and databases on pharmacology and ethnomedicine available on the Internet were searched to identify the plants' known

Red bird mites (chickens) Demanyssus gallinae

Signs

Birds seem to be itching themselves and are irritable. Tiny mites can be seen on birds, eggs, coop or on the handler. There are "Salt-and-pepper" marks near the cracks of the coop.

Causes

There are two main species of bird mites in North America. These are Demanyssus gallinae and Ornithonyssus sy/viarum (northern fowl mite).

Treatment \& Prevention

1. Spread diatomaceous earth in the corners and the cracks of the coop.

2. Put a layer of wood ashes from the stove on the floor of the coop after cleaning the coop.

3. Dust hens with diatomaceous earth.

4. Put ashes and/or diatomaceous earth in hens' dusting places ('dust baths").

5. When setting a broody hen, dust the corners of her nest with diatomaceous earth. Put cedar shavings in the bedding. Put chopped dried tobacco stems (Nicotiana rustica) in the nest, among the eggs the hen is to sit on.

Caution

None.

(Topic author: Jan Bevan)

Figure 1 Data collection form 
chemical compounds and clinically tested physiological effects. This data was incorporated with data on the reported folk uses of the plants, and their preparation and administration in North America and Europe. For each species or genus the ethnomedicinal uses in other countries was noted, followed by a summary of chemical constituents, as well as any known active compounds. This type of ethnopharmacological review and evaluation is based on previous work [25]. The non-experimental validation of the plants is provided in the discussion section of this paper.

\subsection{Validation workshop}

The International Institute of Rural Reconstruction (IIRR) developed the workshop method used in this research [26]. The workshop process results in the selection of ethnoveterinary practices and remedies that can be effectively recommended for use by the general public and farmers to alleviate minor diseases and problems in domesticated animals.

Ten participants with experience in traditional human and ethnoveterinary medicine took part in a participatory five-day-long workshop hosted by the first author and a German ethnoveterinary consultant (Dr. Evelyn Mathias) in October 2003. Two editorial assistants/facilitators also participated. The facilitators asked participants very specific questions about the medicinal plants used [26]. Each animal/livestock species was covered in a morning or afternoon session. At the poultry session there were three farmer participants and one herbalist, who were already acquainted with the participatory workshop method from the previously-held ruminant workshop. They reviewed collectively the previously prepared draft manual on poultry and rabbits that was in turn based on the earlier oneon-one interviews. Guided by the discussions, the poultry and rabbit data was further clarified, edited and included in the user-friendly manual with the information on other livestock species [27] (Figure 2). There was no separate discussion for rabbits.

\section{Results}

Nineteen plants from 12 plant families were documented as used for poultry parasite control, and 11 plants from eight families were used for parasite control in rabbits (Table 1). Most of these plant species are introduced weeds or kitchen herbs. Some details of how preparations were made are outlined below.

\subsection{Leg mites (Cnemidocoptes mutans)}

One cup [250 mL] of cooking oil (e.g. canola or dregs of olive oil) was mixed with a few tbsp [ 50 mL] of sulphur powder and diatomaceous earth. After stirring well this mixture was rubbed on the birds' legs, or their legs

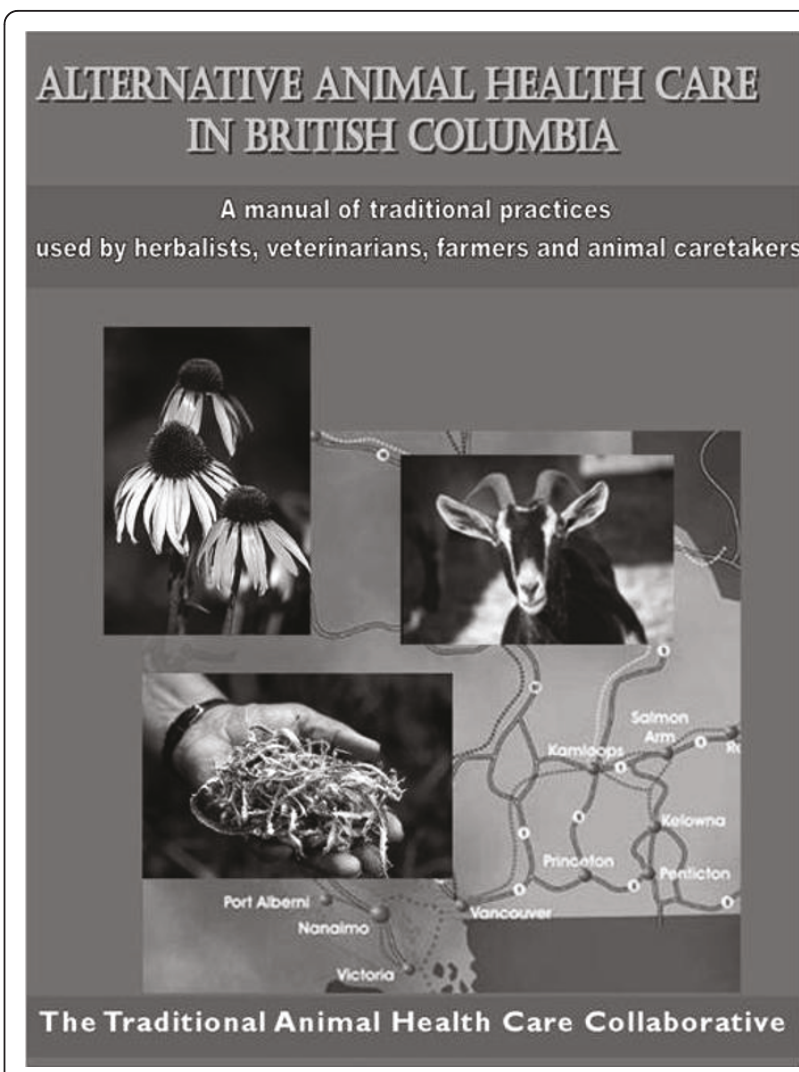

Figure 2 Manual given to all research participants (180 pages).

were dipped in the mixture. This procedure was used to suffocate mites.

\subsection{Internal parasites in poultry}

Poultry were given access to growing epazote (Chenopodium ambrosioides L.) so that they could nibble it. Alternatively handfuls of epazote were thrown to the chickens while they were stilled penned if ample quantities were available. Lambsquarters (Chenopodium album L.) was used as an alternative to epazote and both plants are also considered very nutritious food for poultry. Mugwort (Artemisia vulgaris L.) was grown in the fields or pathways of the farm so that birds could self-medicate. Birds were also allowed to self-medicate with the following herbs: burdock (Arctium lappa L.), comfrey (Symphytum officinale L.), dandelions (Taraxacum officinale Weber), peppermint (Mentha piperita L.), wild Canada thistle (Cirsium arvense (L.) Scop), stinging nettle (Urtica dioica L.), and salmonberry shoots and leaves (Rubus spectabilis Pursh).

\subsection{Caecal/cecal worms (Heterakis gallinarum) and blackhead disease (Histomonas meleagridis)}

A handful of crumbled dry leaves of wild tobacco (Nicotiana rustica L.) (grown on the farm) was added to 
Table 1 Ethnoveterinary medicine used for poultry and rabbits in British Columbia

\begin{tabular}{|c|c|c|c|}
\hline $\begin{array}{l}\text { Scientific name, (botanical family) } \\
\text { Voucher specimen number }\end{array}$ & Local name & Part(s) used & Ethnoveterinary use \\
\hline Acer macrophyllum Pursh (Aceraceae) JB 043 & big-leaf maple & leaves & $\begin{array}{l}\text { bedding - poultry \& } \\
\text { rabbits }\end{array}$ \\
\hline Symphytum officinalis L. (Boraginaceae) JBCL 08 & comfrey & fed fresh or dried leaves & diarrhoea poultry \\
\hline Galium aparine L. (Rubiaceae) JB107 & cleavers & fresh or dried leaves and stems & diarrhoea poultry \\
\hline Papaver somniferum L. (Papaveraceae) JB 114 & poppy & fresh leaves or green pods & diarrhoea poultry \\
\hline Echinacea purpurea (L.) Moench (Asteraceae) JBCI 07 & Echinacea & leaves are chopped and fed & disease prevention chicks \\
\hline Fucus vesiculosus L. (Fucaceae; Brown Algae) JBCL 11 & Kelp & meal added to feed bins every two weeks & disease prevention chicks \\
\hline Ulmus fulva Muhl. (Ulmaceae) not collected & slippery elm & Bark powder in feed for first two weeks & disease prevention chicks \\
\hline Linum usitatissimum L. (Linaceae) not collected & Flax & Ground seed & Starter ration chicks \\
\hline $\begin{array}{l}\text { Ascophyllum nodosum (L.) Le Jolis (Fucaceae) not } \\
\text { collected }\end{array}$ & $\begin{array}{l}\text { Norwegian sea } \\
\text { kelp }\end{array}$ & Dried meal & Starter ration chicks \\
\hline Chenopodium ambrosioides L. (Chenopodiaceae) JBR 36 & Epazote & whole plant & Endoparasites poultry \\
\hline Chenopodium album L. (Chenopodiaceae) JBR 94 & Lamb's quarters & whole plant & Endoparasites poultry \\
\hline Artemisia vulgaris L. (Asteraceae) JB 108 & Mugwort & whole plant & Endoparasites poultry \\
\hline Arctium lappa L. (Asteraceae) CR 100 & common burdock & whole plant & Endoparasites poultry \\
\hline Symphytum officinalis L. (Boraginaceae) CR 35 & Comfrey & whole plant & Endoparasites poultry \\
\hline Taraxacum officinale Weber (Asteraceae) CR 46 & $\begin{array}{l}\text { common } \\
\text { dandelions }\end{array}$ & whole plant & Endoparasites poultry \\
\hline Mentha piperita L. (Lamiaceae) SS024 & peppermint & whole plant & Endoparasites poultry \\
\hline Cirsium arvense (L.) Scop. (Asteraceae) SS030 & wild Canada thistle & whole plant & Endoparasites poultry \\
\hline Urtica dioica L. (Urticaceae) SS023 & stinging nettle & whole plant & Endoparasites poultry \\
\hline Rubus spectabilis Pursh (Rosaceae) JB038 & salmonberry & whole plant & Endoparasites poultry \\
\hline Nicotiana rustica L. (Solanaceae) not collected & wild tobacco & $\begin{array}{l}\text { handful of crumbled dry leaves or } \\
\text { decoction }\end{array}$ & endoparasites poultry \\
\hline Nicotiana rustica L. (Solanaceae) not collected & wild tobacco & chopped stems, seed pods and leaves & external parasites poultry \\
\hline Nicotiana rustica L. (Solanaceae) not collected & wild tobacco & chopped dried stems & red bird mites \\
\hline Thuja plicata Donn ex D. Don (Cupressaceae) JBR 21 & western red-cedar & shavings & red bird mites \\
\hline
\end{tabular}

1 bucket of feed. Alternatively a strong decoction was made by filling a canning kettle with the leaves of the wild tobacco and then pouring water into the kettle until full. The kettle was simmered for a few days until the mixture was reduced to one-fourth of the original amount. One cup $(250 \mathrm{~mL})$ of the resulting decoction was diluted with 1 gallon of water [ca. $5 \mathrm{~L}$ ] and given as the drinking water to the flock. Five gallons of water (with 5 cups [about $1 \mathrm{~L}$ ] of the decoction diluted in it) was said to last for five days (depending on the number of birds in the flock).

\section{Discussion and Conclusion}

The non-experimental validation of the plants is presented in Table 2, in alphabetical order of the plants' scientific names. Table 2 also contains the references numbered $28-68$.

Sulphur is not toxic to mammals and is allowed in pest control in organic agriculture (see http://www.scotland.gov.uk/Publications/2005/05/13153740/37541). Chenopodium ambrosioides is one of the plants that are allowed for pest control [70]. Similarly, farm-grown tobacco is allowed for pest control on organic livestock farms even though the nicotine affects acetylcholine receptors in the nervous system [71,72]. A recent study showed that tobacco bio-oil blocked the growth of the bacteria Streptomyces scabies and Clavibacter michiganensis and the fungus Pythium ultimum (all crop pests). The tobacco bio-oil also killed Colorado potato beetles [73]. Some of the plants used to treat poultry and rabbits are also used to treat pets and pigs in British Columbia. Juniper species oil and Thuja plicata Donn ex D. Don have been previously reported as flea treatments for pets. Juniper berries were used to treat stomach problems in pets $[25,74]$. Mugwort (Artemisia vulgaris L.) used to treat endoparasites in poultry and pigs; was reported for fly control of pets [74]. Echinacea leaves were used for disease prevention in chicks while Echinacea roots were used to treat microbial infections in pigs [25]. Peppermint (Mentha piperita L.) whole plant was used against endoparasites in poultry while the oil was used for stomach problems in pets. Slippery 
Table 2 Non-experimental validation of plants used for parasite control in poultry and rabbits in British Columbia

\begin{tabular}{|c|c|c|}
\hline Medicinal plant & Validation information & Reference \\
\hline Acer macrophyllum & $\begin{array}{l}\text { Big-leaf maple leaves were used as bedding for poultry \& rabbits, but not specifically to control } \\
\text { parasites in the litter. The fallen, dried leaves were raked up in the autumn, and were then stored } \\
\text { for use over the year. The leaf litter has more } \mathrm{Ca}, \mathrm{K}, \mathrm{Mg} \text {, molybdenum (Mo), and zinc ( } \mathrm{Zn} \text { ) than } \\
\text { other trees. The litter decomposes quickly and has a high pH. The leaves contain tannins. }\end{array}$ & {$[28,29]$} \\
\hline
\end{tabular}

Ascophyllum nodosum Norwegian sea kelp (Ascophyllum nodosum) was used as a starter ration for chicks that prevented disease. This species, given as a supplement (2\% DM) for two weeks prior to slaughter to feedlot steers and heifers (Bos indicus $\times$ Bos taurus) decreased the prevalence of enterohemorrhagic Escherichia coli and it may prevent increases in Salmonella species. Supplementation of Ascophyllum nodosum to a diet of fescue hay enhanced immune function in lambs and protected against prolonged heat-induced oxidative stress. The vitamin content of Ascophyllum nodosum is highest in September and February at $500 \mathrm{mg} / \mathrm{kg}$ dry matter. The plant has summer antimicrobial activity but none in spring or winter. Maximal calorific values occur in July in the period of maximum growth.

Arctium lappa

Common burdock whole plant was used for endoparasites in poultry. Traditionally seeds were used [33-35] to purify the blood. Seeds contain chlorogenic acid, caffeic acid, cynarin, lappaol C, arctiin, arctignan $\mathrm{E}$, matareisinol, lappaol $\mathrm{A}$ and $\mathrm{F}$ and Arctigenin. Arctigenin is a lignan with antioxidant and anti-inflammatory activities. Roots and leaves contain chlorogenic acid, caffeic acid, cynarin, quercitrin, arctiin, quercetin and luteolin.

Artemisia vulgaris Mugwort whole plant was used to treat endoparasites in poultry. $300 \mathrm{mg} / \mathrm{kg}$ doses of methanol extracts of the aerial parts of $A$. vulgaris and $A$. absinthium were found to reduce the larval form of Trichinella spiralis in rats. Artemisia scoparia flowers and Artemisia pallens essential oil have shown anthelmintic activity. This use is traditional and was part of a compound remedy used to rid the human body of Taenia with Senna, Spigelia marilandica or Artemisia santonica together with pumpkin seeds and slippery elm bark.

Chenopodium album and Lamb's quarters and epazote whole plants were used for endoparasites in poultry. Chenopodium Chenopodium ambrosioides album possesses anthelmintic activity in vitro and in vivo against mature Haemonchus contortus and its eggs and was slightly less effective than Levamisole. The traditional infusion of Chenopodium ambrosioides used as a vermifuge is safer than using the herb's essential oil. \begin{tabular}{ll}
\hline Cirsium arvense & Wild Canada thistle whole plant was used for endoparasites in poultry. This plant contains lignin, \\
callose and silicon. Taraxasterol has moderate anti-inflammatory activity. Tricin-5-0-glucoside,
\end{tabular} Quercetin-3-O-rhamnoglucoside, Quercetin-3-O-digalactoside, cirsimaritin, pectolinaringen are also found. Some of these compounds have antimicrobial activity

Echinacea purpurea An Echinacea product (containing Echinacea purpurea (L.) Moench 20,000 mg/40 grams) was added [46,47] to chicks' feed, or, alternatively, Echinacea leaves were chopped and fed to chicks. Echinacea enhances immune function in rats by increasing antigen-specific immunoglobulin production. Streptococcus pyogenes, Hemophilus influenzae and Legionella pneumophila were inactivated by Echinacea. Echinacea aerial and root ethanol extract also reversed the pro-inflammatory responses of Staphylococcus aureus (methicillin-resistant and sensitive strains) and Mycobacterium smegmatis but had a lesser bactericidal effect.

Fucus vesiculosus Kelp meal was added to the chicks' feed bins every two weeks: 2 cups (about $500 \mathrm{ml}$ ) for 300 young birds. Soluble fractions of the marine alga Fucus vesiculosus (42.3\% yield) are composed of neutral sugars (18.9-48 g/100 g), uronic acids (8.8-52.8 g/100 g), sulfate (2.4-11.5 g/100 g), small amounts of protein $(<1-6.1 \mathrm{~g} / 100 \mathrm{~g})$, and nondialyzable polyphenols $(0.1-2.7 \mathrm{~g} / 100 \mathrm{~g})$. The main neutral sugars were fucose, glucose, galactose, and xylose. Sulfated polysaccharides may be natural antioxidants.

Galium aparine Cleavers fresh or dried leaves and stems were used for diarrhoea in poultry. This plant has traditionally been used for stomach conditions in North America. The insect antifeedant anthraquinone aldehyde nordamnacanthal (1,3-dihydroxy-anthraquinone-2-al) is found in Galium aparine.

Juniperus sp. (Dermanyssus gallinae) red bird mites in poultry were prevented with cedar shavings in the bedding. The antimycobacterial activity of Juniperus communis roots and aerial parts was attributed to a sesquiterpene (longifolene) and two diterpenes (totarol and trans-communic acid). Transcommunic acid was not a stable compound in this experiment. Juniper leaf essential oil had some effectiveness against Dermanyssus gallinae at $0.14 \mathrm{mg}$ oil/ $\mathrm{cm}(3)$.

Mentha piperita Peppermint whole plant was used against endoparasites in poultry. Peppermint oil has larvicidal activity against Aedes aegypti, Anopheles stephensi and Culex quinquefasciatus mosquitoes. Methanolic, dichloromethane and hexanic extracts of Mentha $\times$ piperita had activity against Giardia lamblia but an infusion did not.

Nicotiana rustica A handful of the chopped stems, seed pods and leaves of wild tobacco (Nicotiana rustica L.) (grown on the farm) was added to the bedding in nest boxes to reduce external parasites. Wild tobacco (handful of crumbled dry leaves or decoction) was used for endoparasites in poultry; the chopped dried stems were used for red bird mites. Anthelmintic activity was found in Nicotiana tabacum. Nicotine was used as an insecticide in the past. 
Table 2 Non-experimental validation of plants used for parasite control in poultry and rabbits in British Columbia (Continued)

\begin{tabular}{|c|c|c|}
\hline Papaver somniferum & $\begin{array}{l}\text { Farmers in our study used leaves and plants of opium poppy (Papaver somniferum) to treat } \\
\text { diarrhoea in their poultry. This implies using the side effects of pain treatment with opioids: hard } \\
\text { dry stools and increased gastroesophageal reflux. Activation of mu-opioid receptors by opoids in } \\
\text { the gastrointestinal tract is responsible for inhibition of gut motility. }\end{array}$ & {$[57]$} \\
\hline Rubus spectabilis & $\begin{array}{l}\text { Salmonberry whole plant is eaten by poultry and said to control endoparasites. This is possibly } \\
\text { based on traditional knowledge since Rubus trivialis was given for scours in sheep and Rubus } \\
\text { strigosus infusion was recommended for diarrhoea. Rubus species berries contain bioactive } \\
\text { flavonoids, including anthocyanins and proanthocyanidins that promote health. }\end{array}$ & {$[35,58,59]$} \\
\hline Symphytum officinale & $\begin{array}{l}\text { Comfrey fed fresh or dried leaves were used for diarrhoea and endoparasites in poultry. The plant } \\
\text { is mucilaginous and high in protein. Self-medicating birds apparently did not ingest enough } \\
\text { pyrrolizidine alkaloids to be harmed and the content of these alkaloids varies from plant to plant. }\end{array}$ & {$[60,61]$} \\
\hline Taraxacum officinale & $\begin{array}{l}\text { Common dandelion (Taraxacum officinale) was used by the participants in our study to treat } \\
\text { endoparasites in poultry, and as food for both poultry and rabbits. Taraxacum officinale pre- } \\
\text { treatment (aqueous decoction of dried herb - } 10 \mathrm{mg} / \mathrm{kg} \text { ) can reduce the severity of cholecystokinin } \\
\text { (CCK)-octapeptide-induced pancreatitis in rats. This plant use is traditional. Many studies conducted } \\
\text { on dandelion extracts or its constituents (polyphenolics and sesquiterpenes) from the leaves or } \\
\text { roots have shown anti-inflammatory and other activities. }\end{array}$ & {$[62-64]$} \\
\hline Thuja plicata & $\begin{array}{l}\text { Western red-cedar shavings were used to protect poultry against red bird mites. Thuja occidentalis } \\
\text { was tested and found to have some effectiveness against the poultry red mite Dermanyssus } \\
\text { gallinae. }\end{array}$ & {$[65]$} \\
\hline Thuja plicata & $\begin{array}{l}\text { Methanol extracts of western red cedar (commonly used for animal bedding) were tested for } \\
\text { antimicrobial activity against anaerobic bacteria and yeast. The test microbes included } \\
\text { Fusobacterium necrophorum, Clostridium perfringens, Actinomyces bovis and Candida albicans which } \\
\text { are found in foot diseases and other infections in animals; the results were not significant. Beta- } \\
\text { thujaplicin is a tropolone-related compound purified from the wood of Thuja plicata. All } \\
\text { Staphylococcus aureus isolates were inhibited by beta-thujaplicin with MICs of } 1.56-3.13 \mathrm{mg} / \mathrm{L} \text {. } \\
\text { However, a paradoxical zone phenomenon occurred, with each isolate producing regrowth at } \\
\text { higher beta-thujaplicin concentrations. }\end{array}$ & {$[66,67]$} \\
\hline Ulmus fulva & $\begin{array}{l}\text { Slippery elm bark powder is put in the feed for the first two weeks for disease prevention chicks. } \\
\text { This use is traditional. }\end{array}$ & {$[35,68]$} \\
\hline Urtica dioica & $\begin{array}{l}\text { Urtica dioica was used for endoparasites in poultry in our study. A leaf infusion of Urtica dioica } \mathrm{L} \text {. } \\
(2.5 \mathrm{~g} \text { dry plant leaves infused in } 1 \mathrm{~L} \text { boiled water) protected rats that were given the chemical } \\
\text { carcinogen trichloroacetic acid. }\end{array}$ & [69] \\
\hline
\end{tabular}

elm (Ulmus fulva Muhl.) was fed to chicks for disease prevention and used for stomach problems in pets $[25,74]$.

Table 2 shows that the anti-parasitic and dietary uses of Arctium lappa L., Artemisia sp., Ascophyllum nodosum (L.) Le Jolis, Chenopodium ambrosioides L., Cirsium arvense (L.) Scop., Fucus vesiculosus L., Galium aparine L., Mentha piperita, Nicotiana sp., Papaver somniferum L., Rubus spp., Symphytum officinale L., Taraxacum officinale Weber, Thuja plicata Donn ex D. Don, Ulmus fulva L. and Urtica dioica L. are supported by ancient and current scientific studies and reports. For example the essential oils from various plants have shown toxicity to different insect pests. Artemisia judaica L., inhibits the normal feeding activity of the cotton leafworm (Spodoptera littoralis), Juniperus occidentalis Hook, has activity against adult mosquitoes (A. aegypti), Xenopsylla cheopis (rat flea) and Ixodes scapularis (tick). Chenopodium ambrosioides L., has activity against Planococcus citri (citrus mealybug) and western flower thrips (Frankliniella occidentalis) [71].

A botanical compound containing Chenopodium ambrosioides L., was significantly more effective against green peach aphid, Myzus persicae (Sulzer) (Homoptera: Aphididae), western flower thrips, Frankliniella occidentalis (Pergande) (Thysanoptera: Thripidae), and greenhouse whitefly, Trialeurodes vaporariorium (Westwood) (Homoptera: Aleyrodidae) than neem oil (Azadirachta indica A. Juss) and insecticidal soap but was not as effective against the whitefly parasitoid Encarsia formosa Gahan (Hymenoptera: Aphelinidae) [70]. Burdock extracts (20 g kg-1) (Arctium lappa L.) protected potato leaves from the larvae of Colorado potato beetle (Leptinotarsa decemlineata (Say)) [75]. The lyophilized extract of burdock leaves demonstrated antimicrobial activity against some bacteria and fungi (Bacillus subtilis, Escherichia coli, Staphylococcus aureus, Micrococcus luteus, Candida albicans, Lactobacillus acidophilus and Pseudomonas aeruginosa) [76]. The essential oil of Mentha piperita L., showed activity against Candida albicans [77]. Mentha piperita L. (methanol and dichloromethane extracts) showed activity against certain yeasts within 24 hours. The most resistant yeasts were C. glabrata and C. utilis, while C. krusei and C. guilliermondii were the most susceptible strains [55]. 
Botanical compound studies on livestock pests have also been conducted (see Table 2). Thuja occidentalis L. arborvitae and Juniper spp. (Juniperus) leaf essential oils were found to be effective against the poultry red mite Dermanyssus gallinae [53,65]; therefore adding these plants to poultry bedding could be recommended. Mentha longifolia auct. non (L.) Huds. (synonym Mentha spicta L.) ethanol and water extracts had 67.1 and $63.1 \%$ efficacy respectively against naturally acquired pinworms (Syphacia obvelata) in mice suggesting the usefulness of certain mint species for endoparasite control [78]. Chenopodium ambrosioides L., has a long history of use against endoparasites. Mice infected with Schistosoma mansoni cercariae were given Chenopodium ambrosioides L., methanol extracts at high concentrations (750 and $1000 \mathrm{ppm})$ and the extracts diminished the cercarial infectivity of the mice [79]. The hexane extract of $C$. ambrosioides L., showed anthelmintic activity in vitro and a reduction of the inflammatory reaction produced by the infection of Toxocara canis larvae in vivo in mice and showed no toxicity [80].

The use of opium poppy (Papaver somniferum L.) for diarrhoea in poultry was based on its opiate activity; opoids would alleviate diarrhoea by hardening the stools [57].

Kelp was fed to chicks and this practice may improve the food safety of organic poultry. The use of kelp is supported by one study which found that Norwegian sea kelp (Ascophyllum nodosum (L.) Le Jolis) given as a supplement (2\% DM) for two weeks prior to slaughter to feedlot animals (Bos indicus x Bos taurus) decreased the prevalence of enterohemorrhagic Escherichia coli and it may prove effective in controlling the spread of Salmonella species [30].

\section{Conclusions}

This study highlights the potential for local, easily available herbal preparations to be used safely and effectively to treat parasites and various other ailments in animals being raised for meat or other purposes. Nineteen species of plants were used for parasite control in poultry. Eleven species were used for parasite control in rabbits. Plants used for treating endo- and ectoparasites included Arctium lappa $L$. (burdock), Artemisia sp. (wormwood), Chenopodium album L. (lambsquarters) and C. ambrosioides L. (epazote), Cirsium arvense (L.) Scop. (Canada thistle), Juniperus spp. (juniper), Mentha piperita L. (peppermint), Nicotiana sp. (tobacco), Papaver somniferum L. (opium poppy), Rubus spp. (blackberry and raspberry relatives), Symphytum officinale L. (comfrey), Taraxacum officinale Weber (common dandelion), Thuja plicata Donn ex D. Don (western redcedar) and Urtica dioica L. (stinging nettle).

Parasitologists have realized that chemoprophylaxis is unsustainable due to increasing drug resistance and the costs of constantly developing new drugs [81]. Certain crop plants can uptake antibiotics from livestock manure applied to the soil. This has implications for human health [14]. The use of botanical products for parasite control would reduce the antibiotic contamination of the soil and lessen the antimicrobial resistance that is developing in certain parasites. Further research is needed to further confirm these preliminary findings on the efficacy and safety of these herbs, but previous studies indicate that their use can be both beneficial and relatively cost effective.

\section{Acknowledgements}

The research in British Columbia was funded by the Social Sciences and Humanities Research Council of Canada (SSHRC) Grant \# 820-2002-1008 in 2003 and 2004.

\section{Author details}

${ }^{1}$ PO Box 72045 Sasamat, Vancouver, British Columbia, V6R4P2, Canada. ¿University of Victoria, School of Environmental Studies, British Columbia, V8W 2Y2, Canada.

\section{Authors' contributions}

$\mathrm{CL}$ conceived of the study, obtained funding for it and participated in its design and coordination. NT supervised the study, helped hire research assistants, facilitated the Herbarium deposits and took part in the workshop. Both authors read, revised and approved the final manuscript.

\section{Competing interests}

The authors declare that they have no competing interests.

Received: 25 May 2011 Accepted: 14 July 2011 Published: 14 July 2011

\section{References}

1. Broom DM: Animal welfare: an aspect of care, sustainability, and food quality required by the public. J Vet Med Educ 2010, 37:83-8.

2. Thompson PB: Animal ethics and public expectations: the North American outlook. J Vet Med Educ 2010, 37:13-21.

3. Lazzaroni C, Biagini D, Lussiana C: Fatty acid composition of meat and perirenal fat in rabbits from two different rearing systems. Meat Sci 2009, 83:135-139.

4. D'Agata M, Preziuso G, Russo C, Zotte AD, Mourvaki E, Paci G: Effect of an outdoor rearing system on the welfare, growth performance, carcass and meat quality of a slow-growing rabbit population. Meat Sci 2009, 83:691-696.

5. USDA (nd). [http://199.133.10.140/codesearchwebapp/\% 28imsm11453yjozkr2ww0n1hin\%29/codesearch.aspx].

6. Maretzki AN, Mills EM: Applying a NutriBusiness approach to increase animal source food consumption in local communities. J Nutr 2003, 133:4031S-4035S.

7. Frank Mitloehner: Livestock's role in climate change: A closer look at 'Livestock's Long Shadow'. California Cattleman 2009, , November: 14-17.

8. Peters Christian J, Wilkins Jennifer L, Fick Gary W: Testing a complete-diet model for estimating the land resource requirements of food consumption and agricultural carrying capacity: The New York State example. Renewable Agriculture and Food Systems 2007, 22:145-153.

9. Kan CA, Keukens HJ, Tomassen MJ: Flubendazole residues in eggs after oral administration to laying hens: determination with reversed phase liquid chromatography. Analyst 1998, 123:2525-7.

10. EMEA: The European Agency for the Evaluation of Medicinal Products. Flubendazol, Summary Report (Extension to Turkeys) Veterinary Medicines Evaluation Unit, Committee for Veterinary Medicinal Products; 1999.

11. Waller PJ: From discovery to development: current industry perspectives for the development of novel methods of helminth control in livestock. Vet Parasitol 2006, 139:1-14. 
12. Nerio LS, Olivero-Verbel J, Stashenko E: Repellent activity of essential oils: A review. Bioresource Technology 2010, 101:372-378.

13. van Krimpen MM, Binnendijk GP, Borgsteede FH, Gaasenbeek CP: Anthelmintic effects of phytogenic feed additives in Ascaris suum inoculated pigs. Vet Parasitol 2010, 168:269-77.

14. Kumar K, Gupta SC, Baidoo SK, Chander Y, Rosen CJ: Antibiotic uptake by plants from soil fertilized with animal manure. J Environ Qual 2005, 34:2082-5.

15. Sertkaya E, Kaya K, Soylu S: Acaricidal activities of the essential oils from several medicinal plants against the carmine spider mite (Tetranychus cinnabarinus Boisd.) (Acarina: Tetranychidae). Industrial Crops and Products 2010, 31:107-112.

16. Soares SF, Borges LMF, de Sousa Braga R, Ferreira LL, Louly CCB, Tresvenzol LMF, de Paula JR, Ferri PH: Repellent activity of plant-derived compounds against Amblyomma cajennense (Acari: Ixodidae) nymphs. Veterinary Parasitol 2010, 167(1):67-73.

17. Mathias-Mundy E, McCorkle CM: Ethnoveterinary Medicine: An Annotated Bibliography Bibliographies in Technology and Social Change No. 6 lowa State U, Ames, lowa, USA; 1989.

18. Statistics Canada: Alternative Livestock on Canadian Farms Canada and Provinces - 1981, 1986, October 2002 1991, 1996 and 2001. Catalogue no. 23-502-XIE; 2002 [http://www.statcan.gc.ca/pub/23-502-x/23-502-×2007001eng.htm].

19. Macey A: The state of organic farming in Canada in 2002 EcoFarm and Garden; 2004

20. Macey A: Certified Organic Production in Canada 2004 Prepared for Canadian Organic Growers and Agriculture and Agri-Food Canada. Ottawa, Ontario; 2005.

21. Reid F: Marketing boards versus organics - the issues 2002 [http://www. trforganic.com/fred.htm].

22. Serecon: A market assessment and program review of the specialty chicken industry in British Columbia and the BCCMB New Entrant program. The British Columbia Chicken Marketing Board Serecon Management Consulting Inc., Edmonton, Alberta, Canada; 2004.

23. Turner NJ, Thompson C, Thompson MT, York AZ: Thompson Ethnobotany Victoria, BC: Royal British Columbia Museum; 1990.

24. Turner NJ, Szczawinkski AF: Common Poisonous Plants and Mushrooms of North America Portland, OR: Timber Press; 1991.

25. Lans C, Turner N, Khan T, Brauer G: Ethnoveterinary medicines used to treat endoparasites and stomach problems in pigs and pets in British Columbia, Canada. Vet Parasitol 2007, 148:325-340.

26. Mundy $P$, Mathias E: Participatory workshops to produce information materials on ethnoveterinary medicine. Paper presented at the International Conference on Ethnoveterinary Medicine: Alternatives for Livestock Development, Pune, India; 4-6 November 1997.

27. TAHCC: Alternative Animal Health Care in British Columbia: a manual of traditional practices used by herbalists, veterinarian, farmers and animal caretakers Victoria, British Columbia, Canada: The Traditional Animal Health Care Collaborative; 2004

28. Turk T, Schmidt MG, Roberts N: The influence of bigleaf maple on forest floor and mineral soil properties in a coniferous forest in coastal British Columbia. Forest Ecology and Management 2008, 255:1874-1882.

29. Bate-Smith EC: Systematic aspects of the astringent tannins of Acer species. Phytochemistry 1978, 17:1945-1948.

30. Braden KW, Blanton JR Jr, Allen VG, Pond KR, Miller MF: Ascophyllum nodosum supplementation: A preharvest intervention for reducing Escherichia coli 0157:H7 and Salmonella spp. in feedlot steers. Journal of Food Protection 2004, 67:1824-8.

31. Saker KE, Fike JH, Veit H, Ward DL: Brown seaweed- (Tasco) treated conserved forage enhances antioxidant status and immune function in heat-stressed wether lambs. Journal of Animal Physiology and Animal Nutrition 2004, 88:122-30

32. Doty MS, Caddy JF, Santelices B: Case studies of seven commercial seaweed resources FAO Fisheries Technical Paper - 281 Rome: Food and Agriculture Organization of the United Nations; 1987.

33. Cho MK, Jang YP, Kim YC, Kim SG: Arctigenin, a phenylpropanoid dibenzylbutyrolactone lignan, inhibits MAP kinases and AP-1 activation via potent MKK inhibition: the role in TNF-alpha inhibition. International Journal of Immunopharmacology 2004, 4:1419-29.

34. Ferracane R, Graziani G, Gallo M, Fogliano V, Ritieni A: Metabolic profile of the bioactive compounds of burdock (Arctium lappa) seeds, roots and leaves. J Pharm Biomed Anal 2010, 51:399-404.
35. Dadd GH: The American cattle doctor: A complete work on all the diseases of cattle, sheep, and swine New York: Orange Judd; 1891.

36. Akhtar MS, lqbal Z, Khan MN, Lateef M: Anthelmintic activity of medicinal plants with particular reference to their use in animals in the IndoPakistan subcontinent. Small Ruminant Research 2000, 38:99-107.

37. Caner A, Döşkaya M, Değirmenci A, Can H, Baykan S, Uner A, Başdemir G, Zeybek U, Gürüz Y: Comparison of the effects of Artemisia vulgaris and Artemisia absinthium growing in western Anatolia against trichinellosis (Trichinella spiralis) in rats. Exp Parasitol 2008, 119:173-9.

38. Bates J, Tilden HA: The Journal of Materia Medica 1866, 5:206.

39. Jabbar A, Zaman MA, lqbal Z, Yaseen M, Shamim A: Anthelmintic activity of Chenopodium album (L) and Caesalpinia crista (L) against trichostrongylid nematodes of sheep. J Ethnopharmacol 2007, 114:86-91.

40. MacDonald D, VanCrey K, Harrison P, Rangachari PK, Rosenfeld J, Warren C, Sorger G: Ascaridole-less infusions of Chenopodium ambrosioides contain a nematocide(s) that is(are) not toxic to mammalian smooth muscle. $J$ Ethnopharmacol 2004, 92:215-21.

41. Green S, Bailey KL, Tewari JP: The infection process of Alternaria cirsinoxia on Canada thistle (Cirsium arvense) and host structural defence responses. Mycological Research 2001, 105:344-351.

42. Della Loggia R, Tubaro A, Sosa S, Becker H, Saar S, Isaac O: The role of triterpenoids in the topical anti-inflammatory activity of Calendula officinalis flowers. Planta Med 1994, 60:516-20.

43. Dutta C P, Ray LP, Roy DN: Taraxasterol and its derivatives from Cirsium arvense. Phytochemistry 1972, 11:2267-2269.

44. Wallace JW: Tricin-5-O-glucoside and other flavonoids of Cirsium arvense. Phytochemistry 1974, 13:2320-2321.

45. Borawska M H, Czechowska S K, Markiewicz R, Socha K, Nazaruk J, Pałka J, Isidorov VA: Enhancement of antibacterial effects of extracts from Cirsium species using sodium picolinate and estimation of their toxicity. Natural Product Research: Formerly Natural Product Letters 2010, 24(6):554-561.

46. Rehman J, Dillow JM, Carter SM, Chou J, Le B, Maisel AS: Increased production of antigen-specific immunoglobulins $G$ and $M$ following in vivo treatment with the medicinal plants Echinacea angustifolia and Hydrastis canadensis. Immunol Lett 1999, 68:391-5.

47. Sharma SM, Anderson M, Schoop SR, Hudson JB: Bactericidal and antiinflammatory properties of a standardized Echinacea extract (Echinaforce): dual actions against respiratory bacteria. Phytomedicine 2010, 17:563-8.

48. Ruperez P, Ahrazem O, Leal JA: Potential antioxidant capacity of sulfated polysaccharides from the edible marine brown seaweed Fucus vesiculosus. Journal of Agricultural and Food Chemistry 2002, 50:840-5.

49. Morimoto M, Tanimoto K, Sakatani A, Komai K: Antifeedant activity of an anthraquinone aldehyde in Galium aparine L. against Spodoptera litura F. Phytochemistry 2002, 60:163-6.

50. John S: Medical Botany of Halifax. The Lancet 1841, II:427-432.

51. Gordien AY, Gray Al, Franzblau SG, Seidel V: Antimycobacterial terpenoids from Juniperus communis L. (Cuppressaceae). J Ethnopharmacol 2009, 126:500-5.

52. George DR, Sparagano OA, Port G, Okello E, Shiel RS, Guy JH: Repellence of plant essential oils to Dermanyssus gallinae and toxicity to the nontarget invertebrate Tenebrio molitor. Vet Parasitol 2009, 162(1-2):129-34.

53. Ansari MA, Vasudevan P, Tandon M, Razdan RK: Larvicidal and mosquito repellent action of peppermint (Mentha piperita) oil. Biores Technol 2000, 71:267-271.

54. Vidal F, Vidal JC, Gadelha AP, Lopes CS, Coelho MG, Monteiro-Leal LH: Giardia lamblia: the effects of extracts and fractions from Mentha $\times$ piperita Lin. (Lamiaceae) on trophozoites. Exp Parasitol 2007, 115:25-31.

55. Hölling JF, Anibal PC, Obando-Pereda GA, Peixoto IAT, Furletti VF, Foglio MA, Gonçalives RA: Antimicrobial potential of some plant extracts against Candida species. Braz J Biol 2010, 70(4):1065-1068[http://www. scielo.br/scielo.php?script = sci_arttext\&pid $=$ S151969842010000500022\&lng=en], [serial on the Internet]. [cited 2011 July 04].

56. Iqbal Z, Lateef M, Jabbar A, Ghayur MN, Gilani AH: In vitro and in vivo anthelmintic activity of Nicotiana tabacum L. leaves against gastrointestinal nematodes of sheep. Phytother Res 2006, 20:46-8.

57. Kurz A, Sessler DI: Opioid-induced bowel dysfunction: Pathophysiology and potential new therapies. Drugs 2003, 63:649-71. 
58. Erna Gunther: Ethnobotany of Western Washington: The knowledge and use of indigenous plants by Native Americans Seattle: University of Washington; 1973.

59. Kellogg J, Ribnicky D, Wang J, Flint C, Kuhn P, Raskin I, Lila MA: Alaskan wild berry resources and human health under the cloud of climate change. J Agric Food Chem 2010, 58:3884-900.

60. Rode D: Comfrey toxicity revisited. Trends Pharmacol Sci 2002, 23:497-9.

61. Wilkinson JM: A laboratory evaluation of comfrey (Symphytum officinale L.) as a forage crop for ensilage. Animal Feed Science and Technology 2003, 104:227-233.

62. Anon: The Veterinarian: Jaundice in ruminants. In The Field Quarterly Magazine and Review. Volume 2. London: Horace Cox; 1871:322.

63. Schütz $K$, Carle R, Schieber A: Taraxacum-A review on its phytochemical and pharmacological profile. Journal of Ethnopharmacology 2006, 107:313-323.

64. Seo SW, Koo HN, An HJ, Kwon KB, Lim BC, Seo EA, Ryu DG, Moon G, Kim HY, Kim HM, Hong SH: Taraxacum officinale protects against cholecystokinin-induced acute pancreatitis in rats. World I Gastroenterol 2005, 11:597-9.

65. Maurer V, Perler E, Heckendorn F: In vitro efficacies of oils, silicas and plant preparations against the poultry red mite Dermanyssus gallinae. Exp Appl Acarol 2009, 48:31-41.

66. Johnston WH, Karchesy JJ, Constantine GH, Craig AM: Antimicrobial activity of some Pacific Northwest woods against anaerobic bacteria and yeast. Phytotherapy Research 2001, 15:586-8.

67. Arima Y, Nakai Y, Hayakawa R, Nishino T: Antibacterial effect of betathujaplicin on staphylococci isolated from atopic dermatitis: relationship between changes in the number of viable bacterial cells and clinical improvement in an eczematous lesion of atopic dermatitis. J Antimicrob Chemother 2003, 51:113-22.

68. Wood George B, Bache F: The Dispensatory of the United States of America Philadelphia: Elliot; 1849.

69. Celik I, Tuluce Y: Elevation protective role of Camellia sinensis and Urtica dioica infusion against trichloroacetic acid-exposed in rats. Phytother Res 2007, 21:1039-44.

70. Chermenskaya TD, Stepanycheva EA, Shchenikova AV, Chakaeva AS: Insectoacaricidal and deterrent activities of extracts of Kyrgyzstan plants against three agricultural pests. Industrial Crops and Products 2010, 32:157-163.

71. Rattan RS: Mechanism of action of insecticidal secondary metabolites of plant origin. Crop Prot 2010, 29:913-20

72. IFOAM nd. [http://www.ffoam.org/growing_organic/1_arguments_for_oa/ criticisms_misconceptions/misconceptions_no7.html].

73. Potera C: Tobacco Bio-oil Kills Agricultural Pests. Environ Health Perspect 2011, 119:a18-a18

74. Lans C, Turner N, Khan T: Medicinal plant treatments for fleas and ear problems of cats and dogs in British Columbia, Canada. Parasitology Research 2008, 103:889-898.

75. Gökçe A, Isaacs R, Whalon ME: Behavioural response of Colorado potato beetle (Leptinotarsa decemlineata) larvae to selected plant extracts. Pest Manag Sci 2006, 62:1052-7.

76. Chan YS, Cheng LN, Wu JH, Chan E, Kwan YW, Lee SM, Leung GP, Yu PH, Chan SW: A review of the pharmacological effects of Arctium lappa (burdock). Inflammopharmacology 2010

77. Tyagi AK, Malik A: Liquid and vapour-phase antifungal activities of selected essential oils against Candida albicans: microscopic observations and chemical characterization of Cymbopogon citratus. BMC Complement Altern Med 2010, 10:65.

78. Kozan E, Küpeli E, Yesilada E: Evaluation of some plants used in Turkish folk medicine against parasitic infections for their in vivo anthelmintic activity. J Ethnopharmacol 2006, 108:211-6.

79. Kamel EG, El-Emam MA, Mahmoud SSM, Fouda FM, Bayaumy FE: Attenuation of Schistosoma mansoni cercarial infectivity to albino mice by methanol extract of some plant species. Pesticide Biochemistry and Physiology 2010, 98:342-348.

80. Reis M, Trinca A, Ferreira MJ, Monsalve-Puello AR, Grácio MA: Toxocara canis: potential activity of natural products against second-stage larvae in vitro and in vivo. Exp Parasitol 2010, 126:191-7.

81. Jackson F, Miller J: Alternative approaches to control- Quo vadit? Veterinary Parasitology 2006, 139:371-384. doi:10.1186/1746-4269-7-21

Cite this article as: Lans and Turner: Organic parasite control for poultry and rabbits in British Columbia, Canada. Journal of Ethnobiology and Ethnomedicine 2011 7:21.

\section{Submit your next manuscript to BioMed Central and take full advantage of:}

- Convenient online submission

- Thorough peer review

- No space constraints or color figure charges

- Immediate publication on acceptance

- Inclusion in PubMed, CAS, Scopus and Google Scholar

- Research which is freely available for redistribution 